\title{
Construction of Economic Law Litigation System for Corporate Social Responsibility
}

\section{Chao Jia}

\author{
Tianjin university, Tianjin, 300072, China
}

\begin{abstract}
Key words: Constructivism; corporate social responsibility; economic litigation system
\end{abstract}
\begin{abstract}
Based on the theoretical basis and content of corporate social responsibility, this paper demonstrates the innovation of the construction of economic law litigation system of corporate social responsibility from the aspects of plaintiff system, subjective scope system, jurisdiction system, litigation cost system and incentive and restraint system. If the specific procedural system design deviates from the entity's value goal, the program itself loses its value and meaning. The construction of the corporate social responsibility system of economic law has always been consistent with the requirements of economic law entities. Corporate social responsibility economic law litigation system in the economic litigation plaintiff qualification is more extensive, including the workers, enterprises and national ad hoc organs. And the scope of its economic litigation can respond to the adjustment of economic law to a certain extent. At the same time, economic litigation has certain characteristics in the jurisdiction system, litigation cost system and incentive and restraint system.
\end{abstract}

\section{Introduction}

At the beginning of the 20th century, the development of enterprises has become the biggest driving force for the rapid economic development, but the enterprises have a negative effect on the society while creating profits. With the negative impact of the production and business activities on the society, Social responsibility has also emerged, the connotation is constantly enriched, the degree of attention is also rising [1] .In recent years, the concept of corporate social responsibility is more and more people's attention, such as in the West, "Fortune" and "Forbes" are Enterprise rankings with the "corporate social responsibility" as one of the criteria [2].

\section{The Basis and Content of Corporate Social Responsibility Theory}

The idea of corporate social responsibility first appeared in the United States in the early 20th century, mainly due to the special institutional background of the United States and the emergence of the American economy in the same period and the emergence of modern large companies. [3] Since then, around the corporate social responsibility, many Scholars have embarked on a wide range of discussions and active research [4]. Since the development of corporate social responsibility has been integrated into the practice of social areas, and this concept is more widely accepted and recognized $[5,6]$ Corporate social responsibility refers to the enterprise through the enterprise system and corporate behavior embodied for all stakeholders to fulfill the various positive obligations and responsibilities, is the enterprise market and related interest groups of a benign response, but also business objectives of the integrated Enterprises in the pursuit of maximizing the interests of shareholders at the same time, also bear the obligation to maintain and enhance social and public interests. In the framework of the stakeholder theory (Figure 1), the corporate social responsibility of the stakeholders, such as shareholders, employees, customers, governments, communities, creditors, and suppliers, is at the perspective of each stakeholder comprehensive evaluation. 


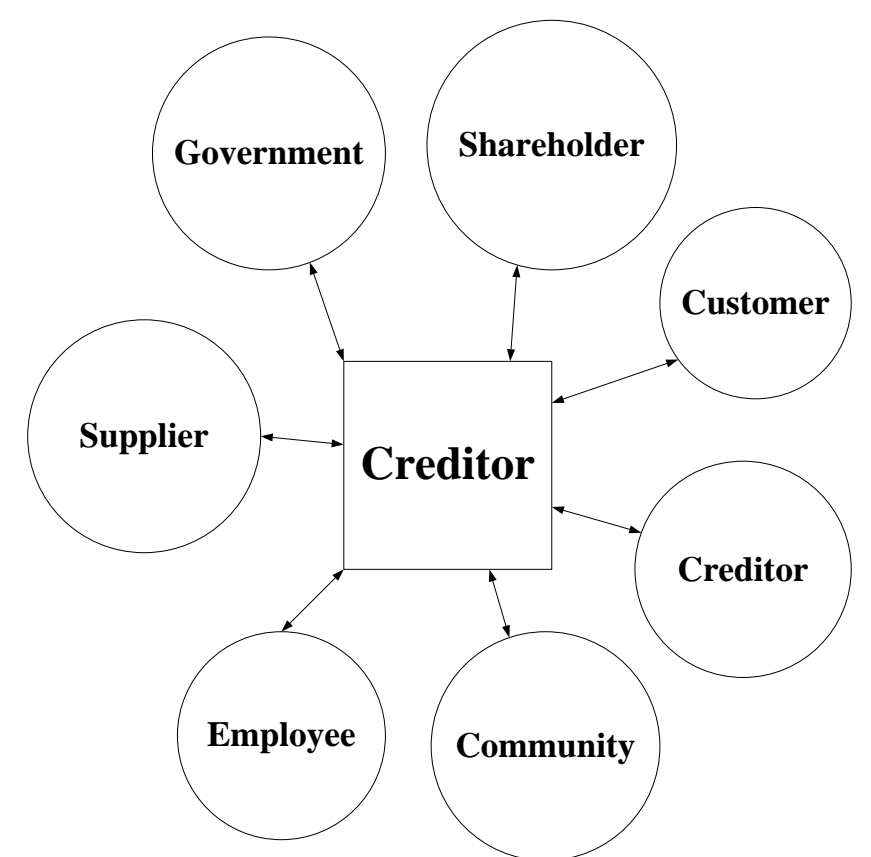

Figure 1. The stakeholder theory

People, enterprises, civil organizations and the government to promote corporate social responsibility movement carried out a series of attempts and practice, and achieved some results. But now also mainly by the enterprise's conscious behavior and moral constraints to maintain. The relevant laws of the state also involve corporate social responsibility, but most of them are principled and indirect, and there is some difficulty in the practical operation level. Therefore, it is necessary to carry out comprehensive investigation and research on the basis of the current situation. Through the sound and perfect legal system, we will actively promote the corporate social responsibility, enhance the corporate social responsibility initiation and behavior awareness, and standardize and guide the corporate social responsibility and behavior, and further clarify the content and requirements of corporate social responsibility, in order to obtain both enterprises and society sustainable and coordinated development of win-win situation.

\section{Understanding of Economic Law Litigation System}

At present, economic law as an independent legal department, its procedural law is not perfect, economic law litigation in practice and can not play its positive role, restricting the development of economic law litigation, economic law litigation independence must be taken seriously The Scholars have discussed more about the mode of economic law litigation, neglected its real goal, and the independence of economic law litigation is of great significance. , The economic law litigation system of the main models are as follows: (a) civil litigation system: Some scholars believe that economic law litigation can be understood as a civil action, but civil litigation, although the economic content, but can not directly understand as Economic law litigation, civil litigation in the economic law litigation content is not comprehensive. (2) Comprehensive economic litigation system: Some scholars believe that economic law litigation is a comprehensive economic litigation, this view recognized the existence of economic law litigation, but there is no more deep understanding of economic law litigation, only the economic content of the law Attributed to economic law litigation, mainly due to the economic law litigation system has not yet established. (3) Independent economic litigation system: Some scholars believe that economic law litigation is an independent economic litigation, at present, the legal system is constantly improving, the legal departments have the corresponding procedural law, with the legal system to further improve the economic law department There will be a corresponding economic litigation law. The purpose of economic law is to maintain 
the overall economic interests, which contributes to the progressive realization of the independent economic procedural law. (4) Public interest economic litigation system: Some scholars believe that economic law litigation is public interest economic litigation, public interest economic litigation is the development of independent economic litigation, the main emphasis is the economic law litigation public welfare essence.

This article attempts to start from the corporate social responsibility, put forward the author's personal views. On the basis of clarifying the boundaries of corporate social responsibility, the legitimacy of the litigation system of economic law is analyzed, and the theoretical support for the corporate social responsibility is found. Advocated the establishment of economic law as the core of the mandatory legal system and the litigation system as the core of the protection of legal norms system. This paper analyzes the use of dialectical thinking through the use of dialectical thinking, through the use of historical and logical, induction and deduction, abstract and concrete, analysis and synthesis of these dialectical thinking methods. In the relationship between theory and practice, based on the actual situation analysis focus on theoretical analysis. The innovation of this paper is to put forward the idea of legalizing the social responsibility of the enterprise and the legal responsibility of the enterprise in violation of the norm. The legal guarantee of corporate social responsibility is legal implement.

\section{The Construction of Economic Law Litigation System under the Social Responsibility of Enterprises}

"The procedure is a technology, but also a relationship, but also a norm, this technology, relations and norms are by the corporate legal person based on a certain value orientation to create and design." If the importance of the program Mainly to ensure that corporate law through the handling of each case in the proceedings to be achieved, substantive justice for the program to provide a unified basis for the support, then, consider the proceedings within the fair, efficient, efficiency, security and other basic value of the target system In addition, the design and composition of the program structure is undoubtedly based on the pursuit of the value of the concept of business, reflecting the requirements of enterprises and workers. If the specific procedural system design deviates from the expected target of the enterprise, the procedure itself loses the value and meaning of being. The construction of the economic litigation system has always been consistent with the requirements of the enterprise. "Enterprise economic litigation system is with the development of enterprise economy, a large number of enterprise economic laws and regulations and gradually from the country's general judicial system in the separation, and gradually form their own corporate economic litigation system.

1. The Construction of Plaintiff System in Economic Law Litigation System.

Enterprise in the economic litigation plaintiff qualification is more extensive, including three major categories of workers, enterprises and national ad hoc organs. With the development of judicial practice, the Court's interpretation of the concept of "interested parties" who have the right to participate in the hearing process and bring the judicial review is becoming increasingly evident from the "obvious party" whose rights, interests or obligations are directly affected. Extended to competitors, consumers, taxpayers, other stakeholders and even "anyone" as indirect relative people. Any employee who sues for the personal economic interests is a prominent feature of the economic law litigation system under the corporate social responsibility. The enterprise is a "legal person" symmetry, which refers to the legal person for the purpose of seeking economic interests. So that certain enterprises as a group litigation of the appropriate parties, on the one hand help to protect the interests of the victims of the entity, on the other hand can reduce litigation and litigation waste and help reduce the cost of procedural benefits. In addition, the national public power can also be restricted. The national ad hoc organ is indispensable as an economic litigation complaint. In the case of litigation involving a wide range of interests, and enterprises as a special group of autonomous organizations, limited representation, the main force of the prosecution is weak and the respondent has a strong, prosecution mechanism is blocked and the country's own interests are damaged, 
litigation without specific plaintiff, The state public power timely intervention, with their own strength and advantages to maintain social welfare become necessary.

2. The Construction of Economic Law Litigation System in Enterprises

The scope of the economic litigation in the enterprise can respond to the adjustment of economic law to a certain extent. By analyzing the real contradictions of social and economic life, combining with the common law of adjusting the object of economic law, reviewing the defects and loopholes in the scope of traditional litigation, and abstracting the scope of the main cases of economic trial. I believe that the anti-unfair competition case, the rights and interests of workers, product quality case, disrupt the financial order case, the economic life of the case of fraud should belong to the economic trial of the scope of the case, because they have at least one common concern Enterprise economic interests, the victims are workers.

3. Construction of Jurisdiction System of Economic Law Litigation System in Enterprises

The term "litigation jurisdiction" refers to the determination of the authority and division of labor between the different levels of courts and between different courts at the same level. In a substantive sense, the lawsuit begins with jurisdiction. Any prosecution of a party shall be made to a specific court. And the jurisdiction of the litigation is the entrance of the court to the specific case of the exercise of the trial power of the prelude to the good litigation entry, to build a fair, reasonable and operational procedures, for the protection of substantive justice is extremely important Practical significance. In judicial practice, for the operation of jurisdiction, prone to jurisdiction of the dispute. Jurisdiction has been controversial, it is necessary to use a certain solution to the dispute, this solution to the dispute, called the alternative. Common jurisdiction disputes and changes have jurisdiction, transfer jurisdiction, transfer jurisdiction. For corporate economic law disputes, the jurisdiction may be different. Some scholars have pointed out the procedural guarantee that the employees should be protected against the specificity of the enterprise disputes and prevent them from being affected by the procedure. They should consider the legislation on economic litigation. "The principle of restricting the establishment of jurisdiction may be conducive to the transfer of the consumer jurisdiction, in order to change the current corporate litigation law is not conducive to the transfer of the consumer jurisdiction system.

\section{Summary}

The content and form of the system is determined by the purpose of the system. "A particular system must be designed on a specific purpose and completed and enriched and developed the structure and system of the system under that particular purpose". The author demonstrates the innovation system of public interest economic litigation in terms of plaintiff system, case scope, jurisdiction system, litigation cost system and litigation mechanism. In the enterprise economic litigation plaintiff qualification is more extensive, specifically includes three categories of workers, enterprises and national ad hoc organs. The scope of the economic litigation in the enterprise can respond to the adjustment of economic law to a certain extent. I believe that the specificity of economic law cases determine the public interest economic litigation should be clearly subject to the scope of the case, only when there is no direct interest in the parties concerned or the state authorized organizations or institutions to protect the interests of the public economic prosecution, or The case of a direct interest relationship is not entirely for the sake of his own interests but for the benefit of the employee, the case can be defined as the scope of the economic court.

\section{References}

[1] Coffee J C. The Globalization of Entrepreneurial Litigation: Law, Culture, and Incentives[J]. 2016.

[2] Harhoff D. Economic cost-benefit analysis of a unified and integrated European patent litigation system[J]. Final Report to the European Commission.(available at http://ec. europa. eu/internal_market/indprop/docs/patent/studies/litigation_system_en. pdf), 2009.

[3] Woo M. The Dynamism of China's Civil Litigation System[M]//The Dynamism of Civil 
Procedure-Global Trends and Developments. Springer International Publishing, 2016: 141-153.

[4] Redish M H. Rethinking the Theory of the Class Action: The Risks and Rewards of Capitalistic Socialism in the Litigation Process[J]. 2014.

[5] Yimin W. The Constructive Learning Theory and English Situated-teaching [J]. Foreign Language Education, 2003, 2: 021.

[6] Kirschner P A, Sweller J, Clark R E. Why minimal guidance during instruction does not work: An analysis of the failure of constructivist, discovery, problem-based, experiential, and inquiry-based teaching[J]. Educational psychologist, 2006, 41(2): 75-86. 